\title{
THE MAINTENANCE OF FOREST TRUCK ROADS IN FOREST MANAGEMENT REGIONS OF SARAJEVO CANTON
}

\section{Održavanje šumskih kamionskih puteva na Šumskogospodarskim područjima Kantona Sarajevo}

\author{
Dževada Sokolović ${ }^{1}$, Muhamed Bajrić ${ }^{1}$, Velid Halilović ${ }^{1}$, Jusuf Musić ${ }^{1}$
}

\begin{abstract}
The time period of forests opening and construction of forest truck roads in the analyzed area is longer than half of century. In such long time interval different types of vehicles for transport of timber assortments have been applied. Due to this fact technical elements of constructed roads are different. The vehicles currently used for the transport of timber assortments cause an accelerated destruction of forest truck roads due to inappropriate carriage way quality. Besides traffic load the forest truck roads are exposed to permanent atmospheric influences. The above specified and other reasons condition obligatory and regular maintenance and reconstruction of forest truck roads depends on the current condition of forest truck roads as well as on the plans for further use.

In this article the condition of forest truck roads in the Forest management regions of Sarajevo Canton has been determined. The most frequent types of damages and causes of their occurrence have been registered. The methods for maintenance and rehabilitation-reconstruction of forest truck roads have been selected and their costs have been calculated. In the time when construction of new kilometers of forest truck roads is more and more rare, timely, adequate and financially justified maintenance of the existing network of forest truck roads is one of the key question for their undisturbed use. On the basis of results obtained in this research the guidelines for the time period and the ways of maintenance of forest truck roads have been given. The application of these guidelines should help in achieving of the best and most economical total results through the long-term use of forest truck roads.
\end{abstract}

Key word: damages, maintenance, influential factors, forest truck roads.

\footnotetext{
${ }^{1}$ Faculty of Forestry, University of Sarajevo
} 


\section{INTRODUCTION - Uvod}

The greatest length of forest truck roads network in the area managed by Public Forest Enterprise "Sarajevo-Sume” (PFE Sarajevo-Sume) was built before several decades. Due to this fact the roads could not fully meet requirements now days. Main reasons for this fact are technical elements and pavement of these roads which were dimensioned in accordance with vehicles for timber assortments transport used in that time. Today vehicles with much greater axle loads are used in forestry. The existing roads were not dimension for such vehicles. Due to this fact there are many significant and numerous damages.

It is known that during one significant time period at the end of previous century building and maintenance of forest truck roads were completely abandoned in this region accompanied with simultaneous exploitation of this roads. Due to this fact condition of forest truck roads were very bad which caused necessity of significant investments in rehabilitation and reconstruction of roads builded focus on stopping of their destruction and recovering their usage value.

The most significant change regarding forest truck roads in postwar period is that Sector for timber assortments transport has been passed into authority of private transporters. Also, more and more private entrepreneurs take stone - pits located in forest, coal mines, etc. under concessions and carry out exploitation and transport of these materials via forest truck roads. Besides specified fact it is important to stress out strengthened interest of local community in forest areas and forest truck roads at the same time.

The forest truck roads are exposed to climate and users impacts. Because of that continuous control of quality status of these roads is needed. Untimely and inadequate intervention on damaged forest truck road could cause unpredictable ecological consequences development of torrential streams, destruction of drinking waters regime etc. At the same time driving through these roads is difficult, slower and causes higher costs due to vehicle damaging. Also, these factors cause reducing value of the road and resources invested in its construction. Due to specified facts the importance of achieving and saving forest truck roads is very clear.

Because of the fact that quality of forest truck roads are achieved and maintenance by construction, exploitation and maintenance it is necessary to determine the impact of each of specified elements on existing condition of forest truck roads. Damages made by construction of low-quality forest truck roads (technical elements, the type and quality of pavement) inadequate exploitation (illicit axle and traffic load, bad weather conditions etc.) and inappropriate and irregular maintenance could be numerous and multiple. Due to these facts it is necessary to take adequate measures for preventing damages. 


\section{RESEARCH GOAL - Cilj istraživanja}

The main goal of this research is determination of quality of existing network of forest truck roads in Forest Management Regions (FMR) managed by PFE "Sarajevo-Sume” and proposal of ways for achievement of the best maintenance effects.

Tasks which should be realized for fulfillment of the goal specified are as follows:

1. Selection of forest truck roads on which terrain recording and measurement will be carried out.

2. Recoding and measuring data on points with mutual distance of one hectometer about pavement, cut and embankment slopes, drainage channels and culverts on selected forest truck roads.

3. On the basis of recoded data on the terrain according to level and intensity of damages for each analyzed forest truck road it is necessary to carry out estimation and calculation of works needed for repairing of recoded damages on forest truck roads and returning roads into full usage functionality.

4. Defining the most frequent damages on forest truck roads of FMR on the basis of given results.

5. Giving proposal of measures for improvement of forest truck roads condition on FMR.

\section{RESEARCH METHOD - Metod istraživanja}

The methods applied within this article are as follows:

- The method of random access was applied for the selection of forest truck roads on which terrain recording and measuring were carried out within all four FMR: Igmansko, Trnovsko, Gornjebosansko i Bistričko. The total length of forest truck roads which has been selected makes $10 \%$ of total length of all forest truck roads in the whole area.

- For collecting data on the terrain the manual was created which is shown in the Table 1 . The condition of forest truck roads has been assessed according to the manual given in the Table 2. Due to easier entering data to assessed possible conditions of specified elements of forest truck roads have been labeled by number (codes) 0,1 and 2 in accordance with damage intensity.

Table 1. The manual for entering terrain data

Tabela 1. Manual za unos terenskih podataka

\begin{tabular}{|l|}
\hline Forest Management Regions: \\
\hline Forest Management Unit: \\
\hline The name of forest truck roads: \\
\hline The total length: \\
\hline Pavement type: \\
\hline The date of measuring: \\
\hline
\end{tabular}




\begin{tabular}{|c|c|c|c|c|c|}
\hline Point label & $\begin{array}{c}\text { Measuring } \\
\text { point }\end{array}$ & $\begin{array}{c}\text { Pavement } \\
\text { condition }\end{array}$ & $\begin{array}{c}\text { Condition } \\
\text { of cut } \\
\text { slopes }\end{array}$ & $\begin{array}{c}\text { Drainage } \\
\text { channels } \\
\text { condition }\end{array}$ & $\begin{array}{c}\text { Culverts } \\
\text { condition }\end{array}$ \\
\hline & & & & & \\
\hline
\end{tabular}

- The data collected from terrain have been processed by statistical methods.

Table 2. The condition on the forest truck roads

Tabela 2. Stanje na šumskim kamionskim putevima

\begin{tabular}{|l|l|c|}
\hline $\begin{array}{c}\text { The road element } \\
\text { condition }\end{array}$ & \multicolumn{1}{|c|}{ Description } & The code \\
\hline \multirow{3}{*}{ Pavement surface } & Good & 0 \\
\cline { 2 - 3 } & Smaller damages (potholes) & 1 \\
\cline { 2 - 3 } & $\begin{array}{l}\text { Big damages (removal of pavement surface, } \\
\text { ploughing) }\end{array}$ & 2 \\
\hline \multirow{3}{*}{ Cut slopes } & Good & 0 \\
\cline { 2 - 3 } & Cleansing needed & 2 \\
\cline { 2 - 3 } & Necessary soil and civil engineering works & 2 \\
\hline \multirow{3}{*}{ Drainage channels } & Good & 1 \\
\cline { 2 - 3 } & Cleansing needed & 2 \\
\cline { 2 - 3 } & Digging needed & 0 \\
\hline \multirow{3}{*}{ Culverts } & Good & 2 \\
\cline { 2 - 3 } & Cleansing needed & 1 \\
\cline { 2 - 3 } & Building needed & \\
\hline
\end{tabular}

\section{RESULTS - Rezultati}

Two forest truck roads of each FMR have been taken for the analysis by random access method. Those are following forest truck roads: Smucka - Orahovica, Orahovica - Odjel 81, Klisura - Bobovica, Dujmovicka brda - Bijela Lijeska, Raskrsce - Kongorje - Podlipnik, Marine Vode - Karaula, Ilijaš - Karašnica and Vukinjača - Doline.

For the listed forest truck roads the terrain data have been collected and costs calculation of all necessary works for rehabilitation has been carried out. On the basis of the above, average costs per $1 \mathrm{~km}$ which are necessary for rehabilitation of each road particularly have been calculated. The graphic illustration of these costs is shown on Graph 1. On the basis given on Graph 1 it is clear that the range of variation of average costs needed rehabilitation of analyzed forest truck roads is very wide and ranges from $3.583 .96 \mathrm{KM} / \mathrm{km}$ needed for the rehabilitation of forest truck road Raskrsce - Kongorje - Podlipnik to $26.675,5 \mathrm{KM} / \mathrm{km}$ needed for the rehabilitation of forest truck road Smucka - Orahovica. Within the range specified there are amounts of 
necessary financial devices for rehabilitation of the other analyzed forest truck roads. The average costs of rehabilitation - reconstruction of analyzed forest truck roads amounts 14.744,19 KM KM per 1 km of roads.

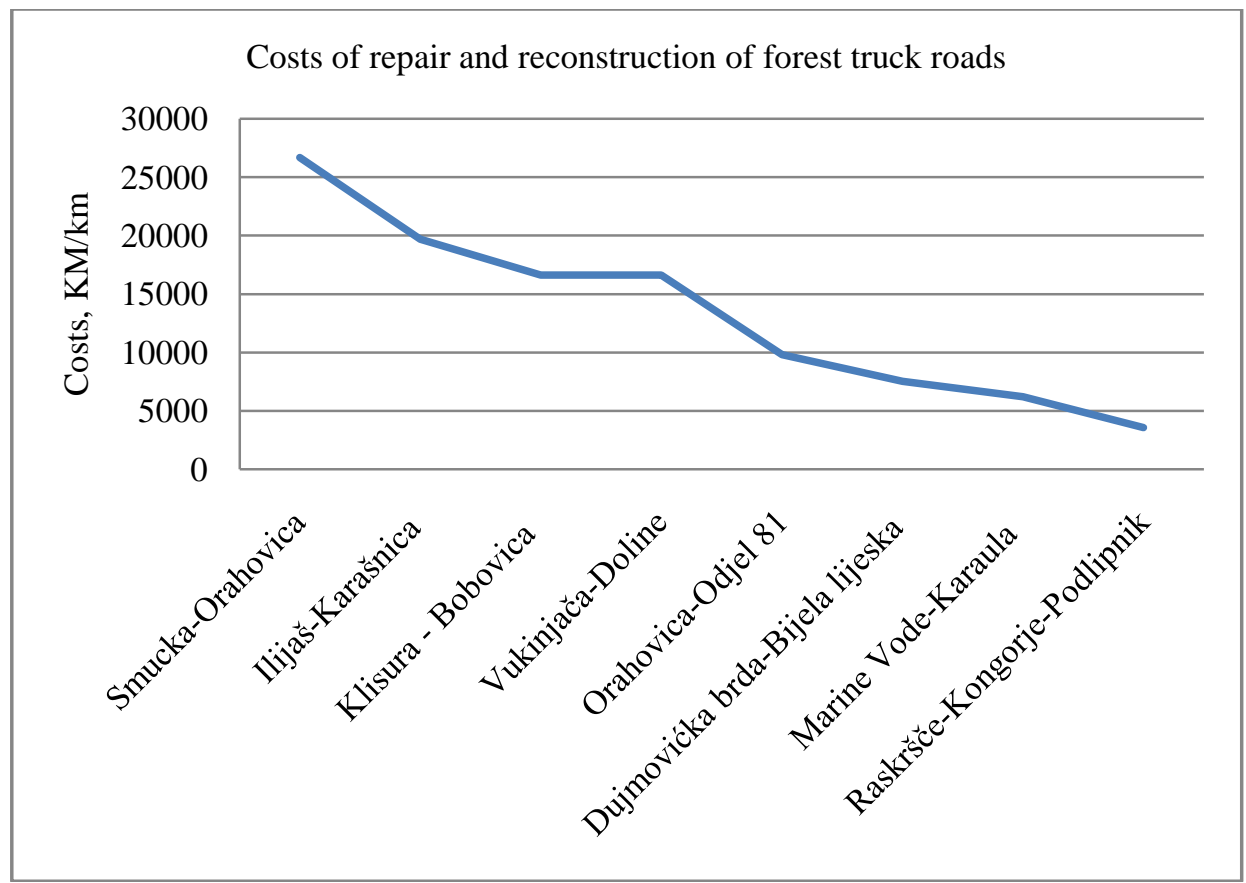

Graph 1. The average costs of rehabilitation - reconstruction of the analyzed forest truck roads Grafik 1. Prosječni troškovi sanacije-rekonstrukcije analiziranih šumskih kamionskih puteva

The calculation for the different types of works needed for rehabilitation reconstruction of the analyzed forest truck roads has been carried out on the basis of data collected on the terrain.

On the basis of data obtained by calculation of volume of all works needed for the restoring of analyzed forest truck roads in the original condition it is clear that the most significant funds should be invested in rehabilitation of pavement surface. These costs ranges from approximately $60 \%$ to $90 \%$ of all rehabilitation costs.

The variation of funds needed for rehabilitation of sinkhole cuts and embankments is very significant. These funds range within interval from approximately $1 \%$ to $21 \%$. For the drainage channel the investment from approximately $4 \%$ to $12 \%$ of total costs is needed. For the cleansing and reconstruction of culverts the investment from approximately $1 \%$ to $30 \%$ of total rehabilitation funds is needed.

The greatest share in total costs rehabilitation - reconstruction of forest truck roads belongs to pavement construction. It is understandable because of the fact that unit costs are the highest for this type of works. 
Different unit costs of rehabilitation of analyzed forest truck roads shown on Graph 1 are the result of different condition of analyzed constructive elements of the road. On the Graph 3 as the example for different unit costs it is shown the participation of particular condition of pavement construction on the analyzed forest truck roads.

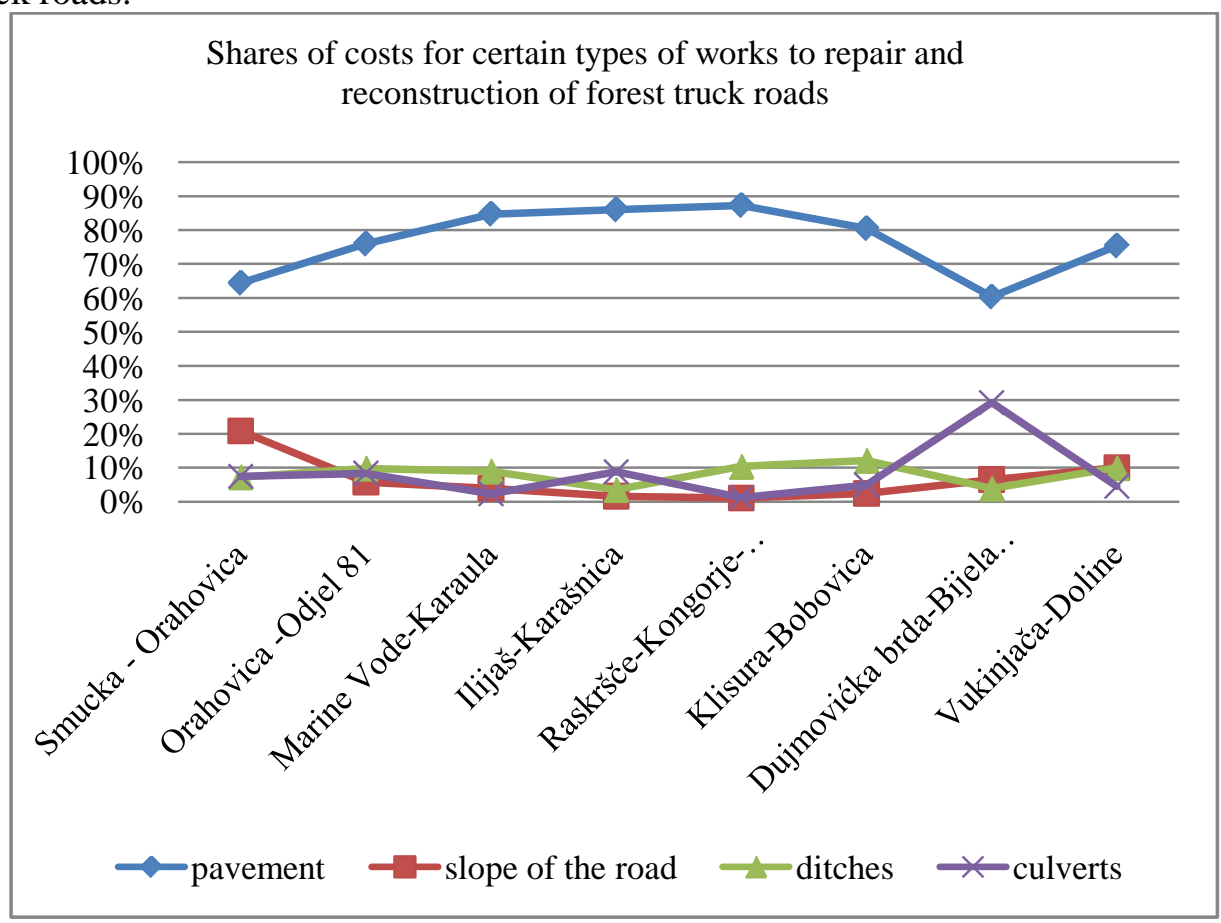

Graph 2. The shares of costs of rehabilitation of particular elements in total costs Grafik 2. Udjeli troškova sanacije pojedinih elemenata puta u ukupnim troškovima

The highest percentage of significant damages on pavement (damage with code 2 - green line on Graph 3) has registered on the roads for which the most significant investments are needed for the rehabilitation, for example the roads Smucka - Orahovica (approximately 80\%) and Ilijas - Karasnica (approximately $70 \%)$. On the road Raskrsce - Kongorje - Podlipnik it has been registered the smallest damage with code 2 (approximately 15\%) while the share of damages with codes 1 and 0 are the equal (approximately 45\%). Due to specified facts for the forest truck road Raskrce - Kongorje - Podlipnik the minimum funds for the rehabilitation are needed.

The wide variation at existing condition of road elements on the analyzed forest truck roads is the result of the numerous factors. The most important of those factors are following: different traffic load, different time of the last rehabilitation reconstruction works on roads and different geological - soil basis. 
Tehnical elements of constructed forest truck roads in this area have been conditioned by the topography of the terrain which is pretty heavy. Because of this fact these roads in horizontal perspective are very tortuous with numerous horizontal curves which are often with minimum radius. In vertical perspective the steep slopes of the road height are very frequent which sometimes exceed maximum allowed slope. The direct consequence of these longitudinal slopes is the accelerated rainfalls swelling. Due to this fact destructive power of water has been increasing which causes rapid rinsing of pavement surface.

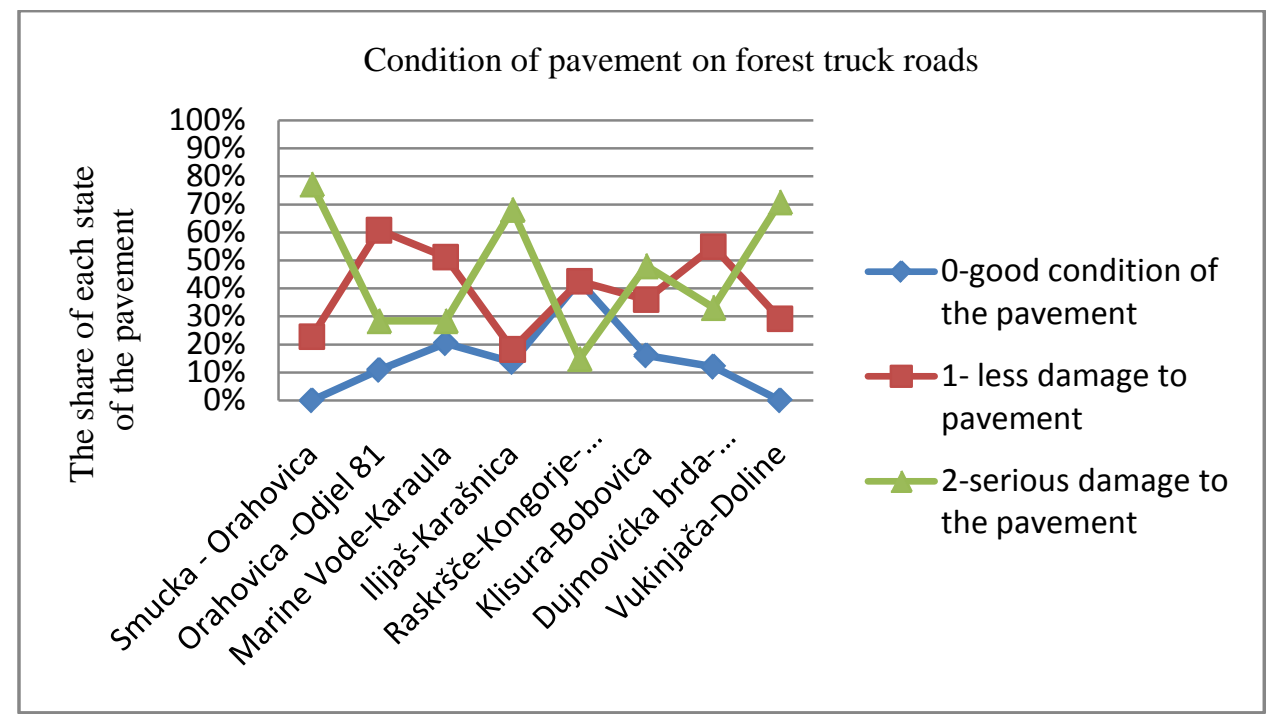

Graph 3. The share of particular types of damages on the pavement on the analyzed forest truck roads

Grafik 3. Udio pojedinih vrsta oštećenja na kolovozu na analiziranim šumskim kamionskim putevima

Besides topography of the terrain the most significant impact on the selection of technical elements of the road belongs to axle load and type of vehicles used for transport of timber. According to the Guidelines for designing of forest roads (Jelicic, 1957) the pavement constructions are dimensioned for maximum load of $10 \mathrm{t}$ or 100 KN per axle. Maximum axle's load of $10 \mathrm{t}$ per axle is in full compliance with maximum axles load on the public roads. The most frequent problem which occurs during transport of timber assortments by modern vehicles of high load-bearing capacity is the total load. The total load must not exceed $40 \mathrm{t}$ according to Rules book on total load allowed on public roads. If it is known that total mass of empty vehicle is $20 \mathrm{t}$, the cargo transported by trucks must not exceed $20 \mathrm{t}$. The permitted axle and total load have been determined due to reasons of road preserving and minimizing of necessary investments in maintenance and reconstruction of the roads. 
For the continuous long-term exploitation of forest truck roads it is necessary to build an adequate type of pavement construction. The pavement construction consists of pavement curtain whose role is to receive the forces caused by vehicle effects (vertical, tangential-longitudinal and tangential-transversal) and transmit them to lower layer. The possibilities for the selection of pavement type are much wider for the soils of good and equally allocated bearing - capacity. For the soils of lower bearing-capacity the selection of pavement construction type is directed towards pavements which equally transmit load on soil (for example cement - concrete pavement and asphalt pavement). The most important starting point for this selection is the economic capability of the company at the moment.

The forest roads have been divided in accordance with material for pavement construction as follows: soil roads, roads with stone pavement and roads with modern pavement. The roads without pavement curtain are soil roads. These roads could be used only in favorable weather conditions for smaller traffic loads. They are not taken into account for the calculation of forest accessibility. The stone pavement according to thickness of pavement construction could be as follows: Mac Adam type, Telford or Sose type and gravel type. In this area of stone pavement the macadam type pavements generally prevail and their total length is approximately $627 \mathrm{~km}$. The modern pavements have been divided into asphalt and concrete pavements according to binder type. The types of pavement are rarer on the analyzed area. According to data from all analyzed FMR the total length of forest asphalt roads amounts approximately $35 \mathrm{~km}$.

The maintenance of forest truck roads according to frequency execution of works has been divided into: regular maintenance and investment maintenance.

Regular maintenance comprises more frequent review (visit) of roads and facilities in order to eliminate possible shortcomings on the pavement, drainage channels, culverts, shoulders and embankments. For the determined damages it is necessary to plan measures, time, material, machines, manpower and costs of the repairing. The regular maintenance includes the winter maintenance. The main objective of the winter maintenance is clearance of snow from pavement in the winter time. The costs needed for regular maintenance depend on the significance and traffic load of the forest truck road.

Meanwhile there are no legal directions which oblige this percentage for investing in regular maintenance of the road. Investment maintenance comprises all major operations during the reconstruction of the road or facilities. The investment maintenance activities are related to pavement construction repairing or replacement of damaged facilities (bridges and culverts), repairing or construction of drainage channels, sinkholes, cuts or embankments, repairing of supporting and protective walls etc.

On the Graph 4. the data on the calculated necessary funds for regular maintenance per analyzed FMR have been given. These costs have been calculated at the level of $1,5 \%$ of construction costs which according to The Report on forests management in Federation of Bosnia and Herzegovina amount $50.000 \mathrm{KM} / \mathrm{km}$. 
According to Graph 4. the regular maintenance costs per analyzed FMR amounts approximately as follows: $84.000 \mathrm{KM}$ for "Igmansko" region, $55.000 \mathrm{KM}$ for "Trnovsko" region, 308.000 KM for "Gornjebosansko" region and $31.050 \mathrm{KM}$ for "Bistričko" region annually. The total costs of regular maintenance for the all analyzed FMR amounts approximately $408.000 \mathrm{KM}$ annually.

On the Graph 4. the calculated funds necessary for the reconstruction of existing forest truck roads network have also been shown. They amount approximately as follows: $886.000 \mathrm{KM}$ for "Gornje-bosansko" region, $223.400 \mathrm{KM}$ for "Igmansko" region, 146.400 KM for "Trnovsko" region and $82.800 \mathrm{KM}$ for "Bistričko" region. The calculated amount anticipates the investments in the reconstruction of the overall forest truck roads network in the amount of $40 \%$ of the construction costs $(50.000$ KM) every ten years.

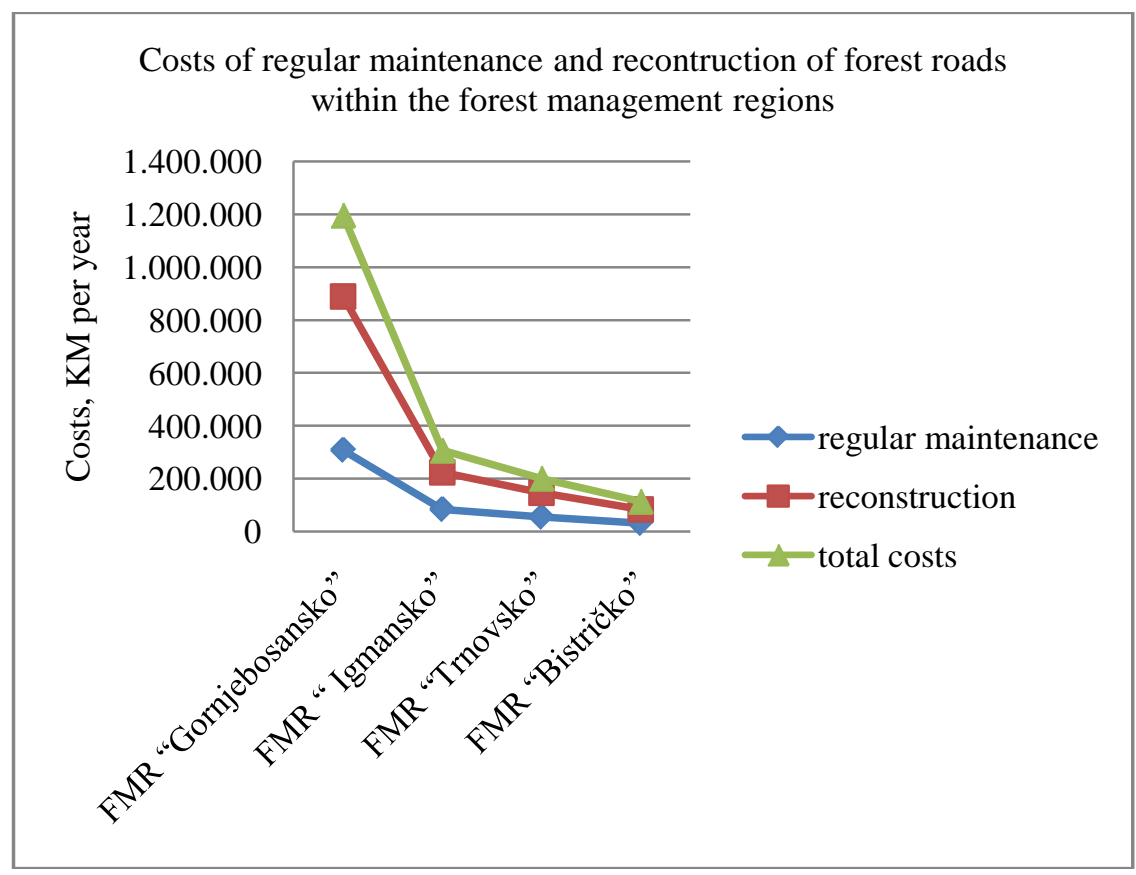

Graph 4. The annual costs of the regular and investment maintenance per FMR Grafik 4. Godišnji troškovi redovnog i investicionog održavanja po ŠGP

On the Graph 4. the total annual costs of the regular maintenance and reconstruction per FMR have also been shown. 


\section{DISCUSSION - Diskusija}

According to the results obtained within this article it is obvious that condition on the analyzed forest truck roads is pretty unequal. The calculated funds necessary for the rehabilitation of the analyzed forest truck roads range from 3.583,96 KM/km for the rehabilitation of forest truck road "Raskrsce-Kongorje-Podlipnik" to 26.675,5 $\mathrm{KM} / \mathrm{km}$ needed for the rehabilitation of the road "Smucka-Orahovica".

The most significant funds should be invested in the rehabilitation of pavement surface. These costs range within interval from approximately $60 \%$ to $90 \%$ of total rehabilitation costs. The roads on which the most damages on pavement have been registered (approximately $70-80 \%$ the road Smucka-Orahovica) require the most significant funds for the reconstruction. For the rehabilitation of sinkhole cuts and embankments on the analyzed forest truck roads it is needed approximately from $1 \%$ to $21 \%$, approximately from $4 \%$ to $12 \%$ for drainage channels and for the clearance and culverts construction it is necessary approximately from $1 \%$ to $30 \%$ out of total funds needed for the rehabilitation. The most important reasons for the specified differences are as follows: the category of forest truck road, traffic load, intensity of regular maintenance, the year of the last rehabilitation of the road, the type of geologic-soil base, hydrographic development etc.

The total costs needed for regular maintenance of FMR managed by PFE "Sarajevo-Sume" have been calculated and they amount $477.675 \mathrm{KM}$ per year. The funds necessary for the reconstruction of the existing network of forest truck roads have also been calculated and they amount 1.341.200 KM per year. The total funds needed for the regular maintenance and reconstruction of forest truck roads in all area amount 1.818.875 KM annually. The calculated costs for the regular maintenance and reconstruction of forest truck roads on the analyzed forest area would be only approximate because there are no adequate data which could be the basis for the calculation of real costs.

The similar results have been obtained by РотосNIK (1996) who emphasizes that pavement construction of all categories of forest truck roads in Slovenia has been equally dimensioned with respect to smooth traffic flow of trucks with semitrailer of total weight of $40 \mathrm{t}$. The author concludes that this approach to forest opening is not rational.

The roads in the FMR managed by PFE "Sarajevo-Sume" are characterized by differences in: technical elements, traffic loads, construction quality, quality and the time of last maintenance, future needs and intensity of usage etc. The specified elements cause different costs of regular maintenance and reconstruction of forest truck roads in the analyzed area. Due to this fact the starting point in the maintenance of forest truck roads in the analyzed area should be inventorying of the existing network of roads. The categorization of forest truck roads would be carried out on the basis of this inventorying.

It is known that forest truck roads have been divided by purpose into: main, side and approaching roads. The roads with the most frequent traffic and the highest 
traffic load (main forest truck roads) due to their technical elements (wider pavement, larger radius of curves etc.) require the most significant funds for regular maintenance and reconstruction. The frequency of the maintenance works of these roads should also be the most often.

The side forest truck roads are characterized by a bit more modest technical elements in the comparison with major forest truck roads. Their quality of pavement construction is also more modest. At the same the intensity of use of these forest truck roads as well as their traffic load are lower to some extent. These are the most important reasons for the lower necessary costs of the maintenance and reconstruction of minor forest truck roads in comparison with major forest truck roads. The time intervals of works on the minor forest truck roads should also be longer in comparison with the major forest truck roads.

The approaching forest truck roads open particular departments. Their maintenance is necessary only if the cutting of timber will be carry out in these forest departments in the next year.

РотосNIK (2005) specifies that forest truck roads in Japan have been divided into three categories in accordance with traffic frequency and importance as follows: main, management and operation roads. The prescribed technical features and construction standard for all these three categories are almost equal. The differences could be noticed in the tasks, frequency and intensity of traffic and maintenance costs of these three categories of forest truck roads.

PотоCNIK (2005) specifies that increasing of standards of reconstruction and maintenance of forest truck roads exceeds needs and capabilities of FMU in the cases when the participation of non-forest traffic is significant or prevailing in the total load and traffic frequency.

In these cases PFE "Sarajevo-Sume" should request financial aid from the State, local authorities or stakeholders who use these forest roads.

\section{CONCLUSIONS - Zaključci}

On the basis of the results obtained within these researches the following conclusions could be derived:

1. The forest truck roads should be maintained due to:

- Possibilities for the secure and quick access to the forest at any time and for all needs for the forest management, providing possibilities for all aspects of forest protection, possibilities for the development of touristic and recreational values of the forest etc.

- Saving of the value of the assets invested in its construction and minimizing of the possibility of occurrences of ecological damages, development of torrential streams, disturbing of waters regime etc. 
2. The starting point in the maintenance of forest truck roads in the analyzed area should be the inventorying of the existing network of the roads which should collect the numerous data from technical elements to traffic load and future planned. It is very important for this data base that it should be saved in the digital form. In this way all further controls and works on the maintenance of the roads would be continuously entered and updated.

3. In the FMR managed by PFE "Sarajevo-Sume" the network of forest truck roads has been built with total length of $650 \mathrm{~km}$ within time interval of 50 60 years with different technical elements, on the different geologic - soil bases. On this network minor or major damages exist. For each forest truck roads it is necessary to make maintenance plans within framework of management units according to determined priority taking into account the importance and existing condition of the road.

4. The continuous control and maintenance of forest truck roads are inevitable because of the fact that the roads are exposed to different atmospheric influences and impacts caused by the ways of use. The continuous control is necessary especially after heavy weather conditions, abundant rain falls, in the unfreezing time impact of high traffic loads and it is included in the regular maintenance. In the framework of regular maintenance besides damages on the pavement the condition on drainage channels, sinkhole, cuts and embankments, shoulders and culverts clearing of stone layers and branches is also supervised. In the winter time the clearance of snow from pavement is comprised in the regular maintenance in order to enable smooth use of the road. When the big holes cover $15 \%$ of total pavement surface or on the surfaces with deformation and deterioration of pavement construction it is necessary to carry out investment maintenance which comprises the pavement restoration. The strengthening of pavement construction by making new pavement layer, replacement of the damaged drainages, rehabilitation of sidings, rehabilitation of damaged supporting walls and included in the investment maintenance. The control of the way of use of the forest truck roads is particularly related to control of axle and total vehicles load which transport timber assortments as well as to weather conditions during use. The driving by means of overloaded trucks, driving during heavy weather conditions after long time periods of rainfalls, driving in the time of the bed unfreezing etc. surely make the enormous damages on the forest truck roads and due to this fact they direct by impact on amounts of funds which should be provided by PFE Sarajevo-Sume for their rehabilitation.

5. The forest truck roads in the analyzed area are used for the needs of PFE Sarajevo-Sume and they are also used by numerous other users from local community to tourists and people during recreation. Due to this fact it is necessary to have better cooperation and coordination of activities amongst all users in order of achieving of better results of the maintenance. 
6. The timely intervention on the forest truck roads will finally result in smaller total costs. The untimely maintenance of forest truck roads causes higher further costs because minor damages which could be repaired relatively cheap, during time, in combination with other influencing factors would make the significant ecology problem and they present potential danger for vehicles and users.

\section{REFERENCES - Literatura}

JELIČIĆ, V. (1985): Pravilnik o uslovima i elementima za projektovanje i izgradnju šumskih puteva, Sarajevo

JeLIČIĆ, V. (1957): Privremeni tehnički propisi za projektovanje šumskih puteva u BiH

KozAR, S., SOKolović, Dž., BAJRIĆ, M. (2009): Moderne kolovozne konstrukcije na šumskim kamionskim putevima, Radovi Šumarskog fakulteta Univerziteta u Sarajevu, No. 1., str. 27-42.

PIČMAN, D. (2007): Šumske prometnice, sveučilišni udžbenik. Šumarski fakultet Sveučilišta u Zagrebu, str. 1-460.

РотоČNIK, I. (1996): Mnogonamenska raba gozdnih cest kot kriterij za njihovo kategorizacijo. Disertacija, Universa v Ljubljani, Biotehniška fakulteta, Oddelek za gozdarstvo, str. 1-241.

POTOČNIK, I., YOSHIOKA, T., MIYAMOTO, Y., IGARASHI, H., SAKAI, H. (2005): Maintenance of forest road network by natural forest management in Tokyo Univesity Forest in Hokkaido, Croatian Journal of Forest Engineering, str. 71-78.

POTOČNIK, I., PENTEK, T., PIČMAN, D. (2005) Impact of traffic characteristics on forest roads due to forest managment, Croatian Journal of Forest Engineering, str. 51-57.

SoKolović, Dž., Gurda, S., ČABARAVDić, A., Halilović, V. (2011): Projekat: Održavanje šumskih kamionskih puteva u Šumsko privrednim područjima Kantona Sarajevo, finansijer: Ministarstvo privrede, Kantonalna uprava za šumarstvo.

SOKOLOVIĆ, Dž., BAJRIĆ, M. (2011): Studija „Šumska transportna infrastruktura“ Federalno Ministarstvo poljoprivrede, vodoprivrede i šumarstva.

SoKolović, Dž. (2008): Uticaji nagiba terena na pravilan izbor vrste šumskog transportnog sredstva, Disertacija, Šumarski fakultet, Sarajevo.

Šumskogospodarska osnova za " Igmansko" Šumskogospodarsko područje. Period važnosti od 01.01.2004.do 31.12.2013. godine.

Šumskogospodarska osnova za „Trnovsko" Šumskogospodarsko područje. Period važnosti od 01.01.2005. do 31.12.2014. godine.

Šumskogospodarska osnova za " Bistričko" Šumskogospodarsko područje. Period važnosti od 01.01.2005. do 31.12.2014. godine. 
Šumskogospodarska osnova za " Gornjebosansko " Šumskogospodarsko područje. Period važnosti od 01.01.2003 do 31.12.2012. godine.

\section{SAŽETAK}

U radu su izvršena terenska snimanja i mjerenja na osnovu kojih je ocijenjeno stanje na analiziranim šumskim kamionskim putevima na ŠGP Kantona Sarajevo kojima gazduje JP „Sarajevo - Šume“. Na osnovu podataka o postojećem stanju urađena je analiza kojom je utvrđena vrsta, obim i troškovi radova kojima bi se putevima vratila puna upotrebna vrijednost. S obzirom da je zatečeno stanje na analiziranim šumskim kamionskim putevima različito, različita su i vrste i obim a time i troškovi radova. Najmanje troškova je potrebno za sanaciju-rekonstrukciju šumskog kamionskog puta Raskršče-Kongorje-Podlipnik i to 3.583,96 KM/km, dok je najviše sredstava potrebno za sanaciju puta Smucka-Orahovica i to $26.675,5 \mathrm{KM} / \mathrm{km}$.

Najviše sredstava je potrebno uložiti u sanaciju kolovozne površine i ovi troškovi se kreću unutar intervala cca $60 \%$ do $90 \%$ od svih troškova sanacije pa je na putevima na kojima je evidentirano najviše oštećenja na kolovozu potrebno najviše sredstava za rekonstrukciju. Za sanaciju škarpi usjeka i nasipa na analiziranim šumskim kamionskim putevima potrebno je cca $1 \%$ do $21 \%$, za odvodne kanale između cca $4 \%$ i $12 \%$ a za čišćenje i gradnju propusta potrebno je cca $1 \%$ do $30 \%$ od ukupnih sredstava potrebnih za sanaciju.

Najznačajniji razlozi za veliko variranje vrste i obima radova te visine troškova za sanaciju-rekonstrukciju analiziranih šumskih kamionskih puteva su: kategorija šumskog kamionskog puta, saobraćajno opterećenje, intenzitet redovnog održavanja, godina posljednje sanacije puta, vrsta geološko-pedološke podloge, hidrografska razvijenost itd.

Na osnovu rezultata koji su se dobili u radu date su preporuke kako bi se postojeće stanje na šumskim kamionskim putevima na analiziranom području unaprijedilo a to su:

- inventarizacija šumskih kamionskih (snimanje postojećih tehničkih elemenata i stanja);

- za svaki šumski kamionski put treba uraditi planove redovnog održavanja i sanacije rekonstrukcije u okvirima gospodarskih jedinica prema utvrđenom prioritetu $\mathrm{s}$ obzirom na značaj puta i postojeće stanje;

- kontinuirana kontrola načina korištenja naročito poslije vremenskih nepogoda, obilnih padavina, u vrijeme odmrzavanja i uticaja velikih saobraćajnih opterećenja;

- koordiniranje aktivnosti svih korisnika šumskih kamionskih puteva od šumarstva do lokalne zajednice, turista i rekreativaca u cilju postizanja što boljih rezultata održavanja. 